\title{
An Innovation Strategy for Public Transit Services using a Public- Private-People Partnership
}

\author{
Myungsik Do, Ph.D. ${ }^{1}$, Wanhee Byun, Ph.D. ${ }^{2}$ and Jung-Beom Lee, Ph.D. ${ }^{3 *}$ \\ ${ }^{1}$ Dept. of Urban Engineering, Hanbat National University \\ ${ }^{2}$ Land \& Housing Institute (LHI) \\ ${ }^{3}$ Daejeon Development Institute \\ ${ }^{1}$ msdo@hanbat.ac.kr, ${ }^{2}$ whbyun@lh.or.kr, ${ }^{3}$ rutgerskg@gmail.com
}

\begin{abstract}
This paper proposes an integrated service management system for a public-privatepeople partnership (PPPP or 4Ps) of public transit services. In accordance with the trend to disclose public information, sharing the current large volume of public data with public and private companies and promoting the efficiency of financial affairs together with service assurance are critical issues for public transit services. Most local governments provide financial support to private bus companies in order to promote individual mobility by using a deficit covering method. However, local government's role is not only in transit service operations but also in service quality control under bounded financial capability. Taking the complexity and uniqueness of public transit services into account, this study proposes a systematic framework based on the principle of publicprivate-partnership (PPP or 3Ps) to outline the elements and associated guidance required for knowledge-based public transit services. Further, the concepts of the disclosure of public information and evaluation of public services are embedded into such planning in order to offer self-evolutional public transit services. An interactive transit service promotion mechanism can be established by cooperation between a private sector monitoring group and an academic and non-government organization (NGO) evaluation support group. The goals of the monitoring group are to check periodically overall transit services based on evaluation categories and to report evaluation records to the government on the internet. In this paper, the performance and overall scheme of a public and private partnership in the public transit service of Daejeon Metropolitan City is used as a case study.
\end{abstract}

Keywords: Public-private-people partnership; public transit services; innovation strategy; information disclosure; knowledge-based management

\section{Introduction}

Improved decision-making is perhaps the most promising element in electronic government (e-government). Further, the central idea in all decision-making is how to provide the optimum solution and how to obtain acceptance of a decision by citizens. Many politicians, administrators, and citizens are interested in increasing citizens' participation in public decisions. Such participation is a growing part of decision-making, although it remains troublesome in practice. In this context, Tulloch and Shapiro (2003) explored possible combinations that could exist between the presence and absence of access and participation in environmental decision-making areas.

Some initiatives are unable to work because administrative systems that are based on expertise and professionalism leave little room for a participatory process (King et al., 1998). Authentic participation by citizens, that is, participation that works for all parties

${ }^{*}$ Corresponding Author 
and stimulates interest and investment in both administrators and citizens, requires a rethink of the underlying roles of, and relationship between, administrators and citizens (King et al., 1998). Table 1 summarizes the key differences between unauthentic and authentic participation models.

Table 1. Comparison of Authentic and Unauthentic Participation (King et al., 1998)

\begin{tabular}{|c|c|c|}
\hline & Unauthentic participation & Authentic participation \\
\hline Interaction style & Conflictual & Collaborative \\
\hline $\begin{array}{l}\text { Participation is } \\
\text { sought }\end{array}$ & $\begin{array}{l}\text { After the agenda is set and } \\
\text { decisions are made }\end{array}$ & Early; before anything is set \\
\hline Role of administrator & Expert technician/manager & $\begin{array}{l}\text { Collaborative } \\
\text { technician/governor }\end{array}$ \\
\hline $\begin{array}{l}\text { Administrative skills } \\
\text { needed }\end{array}$ & Technical; managerial & $\begin{array}{l}\text { Technical, interpersonal skills, } \\
\text { discourse skills, facilitation } \\
\text { skills }\end{array}$ \\
\hline Role of citizen & Unequal participation & Equal partner \\
\hline $\begin{array}{l}\text { Citizenship skills } \\
\text { needed }\end{array}$ & None & $\begin{array}{l}\text { Civics, participation skills, } \\
\text { discourse skills }\end{array}$ \\
\hline $\begin{array}{l}\text { Approach toward } \\
\text { "other" }\end{array}$ & Mistrust & Trust \\
\hline $\begin{array}{l}\text { Administrative } \\
\text { process }\end{array}$ & Static, invisible, closed & Dynamic, visible, open \\
\hline Citizen options & Reactive & Proactive or reactive \\
\hline Citizen output & Buy-in & Design \\
\hline Administrator output & Decision & Process \\
\hline Time to decision & $\begin{array}{l}\text { Appears shorter and easier but } \\
\text { often involves going back and } \\
\text { "redoing" based on citizen } \\
\text { reaction }\end{array}$ & $\begin{array}{l}\text { Appears longer and more } \\
\text { onerous but usually does not } \\
\text { require redoing because } \\
\text { citizens have been involved } \\
\text { throughout; may take less time } \\
\text { to reach decisions than through } \\
\text { traditional processes }\end{array}$ \\
\hline Decision is made & $\begin{array}{l}\text { By administrator/politician } \\
\text { and/or administrative processes } \\
\text { perhaps in consultation with } \\
\text { citizens }\end{array}$ & $\begin{array}{l}\text { Emerges as a result of } \\
\text { discourse; equal opportunity } \\
\text { for all to enter the discourse } \\
\text { and to influence the outcomes }\end{array}$ \\
\hline
\end{tabular}

Given the general decline in the provision of public services, new approaches are being devised with a view to increasingly realigning the responsibilities between the public sector, the private sector, and civil society. With the increase in the size of the system, the role of the government or municipal authorities becomes important (Chakrabarti et al., 2009). It is expected that the private sector, with its dynamism and flexibility, can fill service delivery gaps by forming partnerships with the public sector. Such partnerships can support the private sector with the payment of service charges; but more importantly, they can play an active role in improving the accountability and service quality of both the 
public and private sectors. However, a radical shift in the role of citizens from passive service receivers to active service partners may not occur endogenously (Ahmed and Ali, 2006).

Almost all of the world's population growth between 2000 and 2030 is expected to be absorbed by the urban areas of the less developed regions (UN, 2004). There is likely to be a corresponding rapid increase in the demand for transit services. However, municipalities lack the financial resources and skills needed to cope with this problem. This raises the important issue of how to deliver a quality service in the face of the financial and skill constraints of the public sector. Under a public-private partnership (PPP or 3Ps) arrangement, public and private sector agencies share responsibility for providing a service. The arrangement can take many forms, but the common distinguishing feature is a shared governance structure and decision-making process. Moreover, a third tier, the people, is often overlooked in the service delivery framework. Citizens can contribute significantly to service delivery and improve it by supporting the private sector to form a partnership with people. This paper examines the role of facilitating agencies in developing a tripartite "public-private-people" partnership for the public transit service in Daejeon Metropolitan City, Korea.

In Daejeon, a facilitating agency has attempted to link citizens to the public and private sector to achieve effective public transit service delivery. The involvement and the success of the facilitating agency have varied compared to other cities, presenting an opportunity for an investigation into the work and effect of the public-private-people partnership (PPPP or 4Ps) in the public transit service. In this regard, the project management unit in Daejeon has attempted to build a relationship among the municipality, the private sector, and citizens through joint exercises such as seminars and public meetings.

This paper documents that it is possible to achieve a 4Ps model. A strong partnership was observed in Daejeon, where the municipality, a non-government organization (NGO), and citizens work together for an improved public transit service. The main findings of the study are as follows.

- One of the major contributions of the facilitating agency has been to inject new ideas of service delivery under the 3Ps model.

- A significant achievement has been to build a relationship among the municipality, the NGO, and the citizens.

- The facilitating agency must have sufficient expertise in order to support the 3Ps model successfully.

- The most significant contribution of the facilitating agency has been the demonstration of a workable partnership model and the bridging of the gaps among the public sector, the private sector, and citizens. The facilitating agency has bridged these gaps through consultative meetings and the creation of platforms for discussion.

- The public sector lacks the capacity to conceptualize and implement innovative approaches. The public sector does not have the funds for experimentation with alternative approaches. It also has limited access to the latest advancements in management and technology. The facilitating agency has made new ideas available to the public sector and built its capacity through training and workshops.

- It is not possible for the private sector to conduct advocacy for the 3Ps model. The facilitating agency has acted as an intermediary for the public sector, the private sector, and citizens. This has improved access amongst the three stakeholder groups. 
In general terms, the public and the private sectors are used to working separately and the concept of partnership is foreign to them. Therefore, a third party is often responsible for bringing the two sectors together to form a 3Ps model. In a traditional arrangement, the public sector provides a service but is not directly accountable to citizens. The citizens complain about a poor service through policymakers. This is the "long route of accountability" that is often not very effective. Citizens also buy goods and services from the private sector. In this case, the service provider is directly accountable to citizens through the "short route of accountability" because poor service immediately results in a loss of business. The 4Ps model provides a marriage of the two accountability routes. When the 4Ps model is applied for a common cause such as a public transit service, both the long and short routes of accountability are in force.

In this paper, an innovative strategy is introduced to improve public bus services in Daejeon using the 4Ps concept to promote public transport and to pursue the aim of developing public transport's future. Further, in order to settle the city's traffic problems, national and international examples of innovative strategies about people's participation are compared. Finally, supporting traffic service methods are described in creative cities based on current knowledge including that of expert groups.

\section{Innovative Strategies that Support Public Transport Services using the 4Ps Model}

\subsection{Study of Existing Cases}

Since the mid-1990s, the introduction and expansion of information and communication technology (ICT) such as information technology (IT), biotechnology (BT), and nanotechnology (NT) have brought about significant technology innovation. The propagation of the internet and mobile phones has changed our lifestyles and behavior patterns (Yigitcanlar and Lee, 2014). However, as a result of this growthoriented policy, social polarization and severe environmental problems have occurred. In the transport field, the rapid growth of the number of private cars has led to many problems such as noise, dust, traffic congestion, and traffic accidents. In addition, most cities have faced a problem with transport support services and the need to help with the transportation issues of vulnerable and lower income groups. Providing public transportation such as bus services and the metro is regarded as an alternative to resolving traffic, environmental, and transport support problems.

Various activities based on experience and knowledge accumulated from daily life have been used to develop sustainable cities. Community-based innovation activities, which combine community activities in a local unit with technology innovation and the Living Lab approach, reflect users' viewpoints in the innovative process and are typical innovative activities in which people (users) participate. The connection between users' participatory activities and public transport service improvement has not yet been determined but is considered by the 4Ps methodology in this paper. Community-based innovation is a concept that combines community action in a location unit with technology innovation and is conducted on a social economic basis such as a social enterprise or cooperative association. In addition, community-based innovation focuses on cooperation among citizens and a common realization of value rather than economic benefits. For example, the Community Innovation for Sustainable Energy (CISE) scheme is a typical example that uses 12 steps to target local communities (Seyfang et al., 2013). The CISE scheme operates a community-owned renewable energy power plant and provides the type of energy that users want to be supplied with.

The Living Lab, which is also called the user-centered open innovative ecosystem, was 
constructed to reflect users' viewpoints and enables users to participate in innovation activities. It was established by William J. Mitchell, a professor of the Urban Planning Department at the Massachusetts Institute of Technology (MIT) (Eriksson et al., 2005). The Living Lab is an open innovative model that settles problems with the active participation of the final users in certain locations or regions and enables development that reflects the needs of regions and users. Recently, users have also participated in development activities by providing development ideas. The Living Lab has been extended to the 4Ps model, in which the public sector, the private sector, and people come together from the existing 3Ps model and in which the gap among the steps of technology development can be reduced by mutual operations. In addition, because the Living Lab includes users' participation, cooperation between the public and private sectors, open innovation, and the utilization of ICT, it has the benefit of being able to settle local problems and treat sustainable development issues flexibly (Alcotra, 2011). As of October 2013, the Living Lab has spread to encompass 354 projects and this trend of growth is ongoing. $287(80.6 \%)$ of the 354 Living Labs are in Europe and 67 (19.4\%) are distributed elsewhere. The activities of the Living Labs tend to focus on citizens and local societies and cover issues such as energy, residences, traffic, training, and health (Song et al., 2013). As a result of the investigation about the Living Labs' activity disciplines by Alcotra (2011), it is understood that the development activities are connected closely to actual living. For example, areas such as energy, architecture, traffic, logistics, health, and well-being account for over half of the overall activities.

In Korea, 4Ps models exist in the environmental sector but there are almost none related to traffic issues. However, citizen monitoring groups that evaluate city bus services similar to the one in Daejeon are benchmarking the activities in Daejeon and enforcing these in the cities of Seoul, Daegu, Jeonju, and Gwangju. In particular, Jeonju city is collecting and evaluating information on four sectors, safe driving, operational status, the level of kindness, and vehicle management with the help of approximately 100 monitoring members through the "Agenda and Meetings for Public Transport in Jeonju" (http://bus.green21.or.kr/) (see Table 2). The results are collected to create an analytical report and utilized to help establish policy in Jeonju for bus enterprises.

Table 2. Evaluation Items of City Buses According to the Jeonju Monitoring Group

\begin{tabular}{l|l}
\hline Description & Evaluation item \\
\hline Safe driving & $\begin{array}{l}\text { Sudden departure, sudden braking, sudden change of lane, start driving } \\
\text { while car door open, speeding, wild driving, and violation of traffic } \\
\text { regulations }\end{array}$ \\
\hline $\begin{array}{l}\text { Operational } \\
\text { status }\end{array}$ & $\begin{array}{l}\text { Failure to stop, suspension of service, adequacy of route signs, and } \\
\text { adequacy of automatic guidance announcements }\end{array}$ \\
\hline $\begin{array}{l}\text { Level of } \\
\text { kindness }\end{array}$ & $\begin{array}{l}\text { Attitude to passengers' questions, driving attitude (whether using mobile } \\
\text { phone), driver's attire, and consideration for vulnerable traffic }\end{array}$ \\
\hline $\begin{array}{l}\text { Vehicle } \\
\text { management }\end{array}$ & $\begin{array}{l}\text { Status of heating, cooling and ventilation, vehicle's external cleanliness, } \\
\text { vehicle's internal cleanliness, damage to internal facilities, and checks on } \\
\text { the availability of major facilities }\end{array}$ \\
\hline
\end{tabular}

Daegu also makes an effort to improve its bus service by evaluating the kindness of drivers, failure to stop, violation of traffic signals, speeding, wild driving, safety, guidance announcements, and the status of facilities inside the buses. To achieve this, Daegu has 300 monitoring group members with three for each city bus route (www.dgag21.or.kr). In 
Gwangju, 180 monitoring group members check 2018 drivers and 910 vehicles. Drivers and bus companies can receive strong penalties depending on the results of evaluations (www.gwangju.go.kr). After giving several warnings, Gwangju has a regulation that enables the city to stop drivers and bus companies from operating, suspend them, and dismiss them.

\subsection{The 4Ps Concept and the Use of a Citizen Monitoring Group for the City Bus Service in Daejeon}

In order to improve a public transport system, the level of service should be maintained or enhanced. To do this, and as part of the process of investigating the service satisfaction level among public transport users, this paper introduces the example of Daejeon, where a systematic operation is conducted using the 4Ps concept.

The citizen monitoring group of the city bus service in Daejeon established a plan for public transport service improvement together with the users and introduced the 4Ps concept. In addition, evaluation items and their weights were determined by the monitoring group in order to secure a fair evaluation process. The results obtained from the service satisfaction investigation on the city bus service are incorporated into the following year's policy by the city authorities. This approach enhances public transport by improving the service for city bus users and modifying the evaluation items.

First, according to the activities and function of each participant body supporting the citizen monitoring group of the city bus service in Daejeon, municipalities (public) have provided a free transfer and sharing system to the other means of transportation (metro, bicycle, etc.) in order to enhance public transport. They have also introduced a Bus QuasiPublic Operating System in order to provide a low-price transport service to citizens through administrative and financial support. In addition, bus companies (private) regularly conduct training for bus driving and control, ensure their drivers act with kindness and drive safely, and act upon complaints notified by the investigation into the satisfaction level of the service. People act as members of the monitoring group for the city bus service and as users at the same time. Civil society (in the case of Daejeon, this is represented by the Daejeon council of 21 members) selects the city bus monitoring group and supports its activities. The council has a critical supervisory role with the citizen monitoring group (see Figure 1).

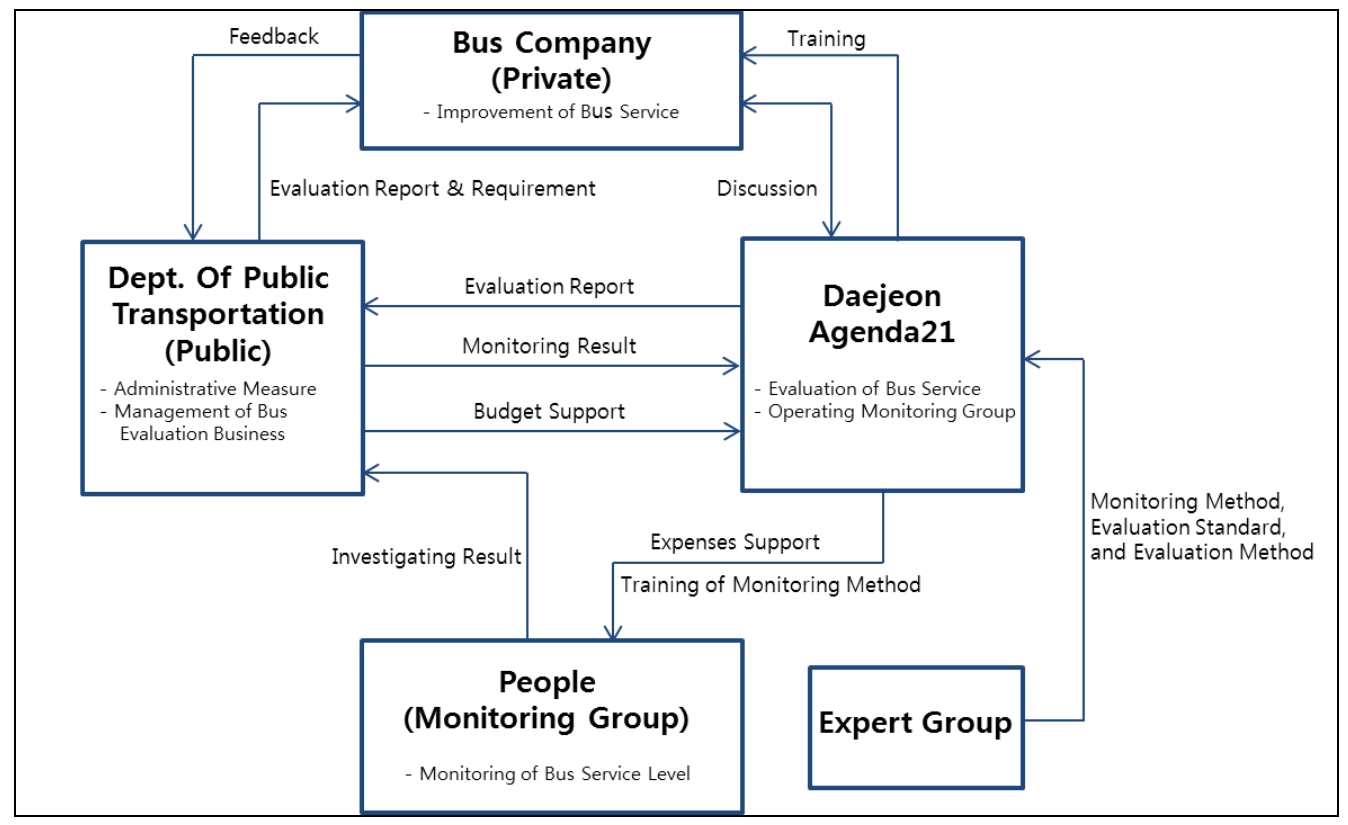

Figure 1. A Conceptual Representation of the 4Ps Model 
The main bodies of the 4Ps model are civil society, representing citizens and the public transport department, and the labor union that represents the drivers of the bus companies (Figure 2). In order to evaluate the service fairly, an advisory group composed of professors, researchers, public service managers, broadcasters, and civil society representatives is in charge of the selection of the evaluation standards and the determination of the weights for each standard.

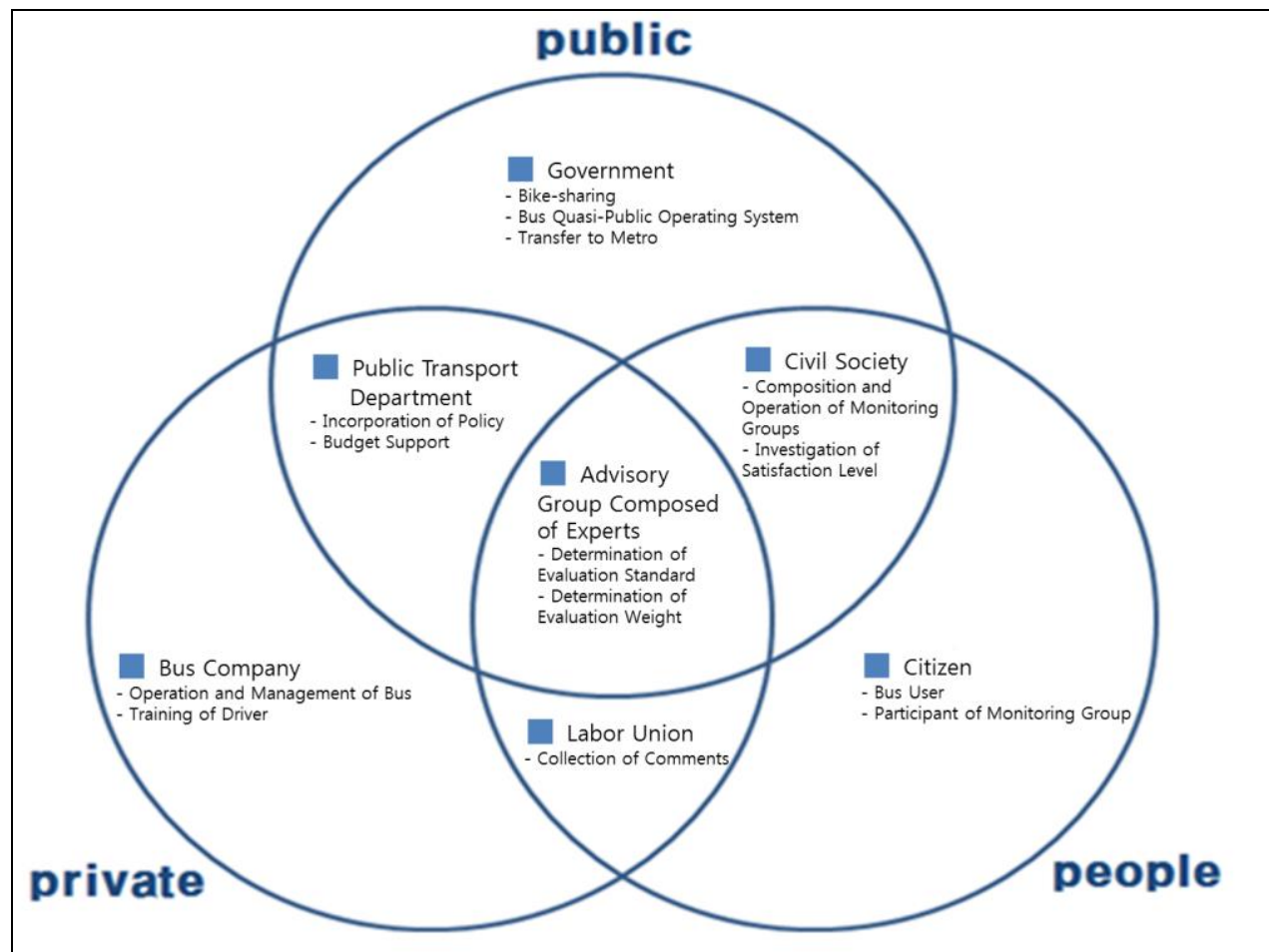

Figure 2. Interrelationships of the 4Ps Model in the Public Transit Service

Daejeon has operated the citizen monitoring group for its bus service since 2008 . Information for over 20,000 events, including complaints and compliments, has been evaluated and uploaded by approximately 250 monitoring members every year. The aims of the monitoring group are to identify kind drivers and companies that provide a high quality service and compliment them. A further aim is to establish the effect on service improvement with regard to all of the bus companies and transport-related organizations and people. Some of the individual citizen monitoring groups in each route evaluate the use of buses from January to December every year and also consider in detail the drivers, the circumstances of use, and operational status as follows.

- Driver: evaluation of attire, kindness, and driving attitude.

- Circumstances of use: guidance announcements, cleanliness, noise, route signs, and status of facility management.

- Status of operation: evaluation of sudden departure, sudden braking, and wild driving.

Evaluation items have been almost the same every year and the scores (the weights of the evaluations) have not changed significantly. However, the evaluation items have largely improved through the deliberation of the expert advisory group by deleting items or reducing scores. In particular, because the items for drivers' attire and greeting level for passengers were recently improved, issues that accounted for high weights when initially introduced in 2008, their scores have reduced. According to the detailed evaluation items in 2012, 40 scores for safe driving, 20 for kindness, 20 for the guidance system, and 20 
for vehicle control have been distributed. In addition, a recently introduced item considers whether drivers give a ride to passengers to the bus bay for their convenience and safety.

Table 3. Evaluation Items and Scores of the Daejeon City Bus Service

\begin{tabular}{|c|c|c|}
\hline Classification & Evaluation item & Score \\
\hline \multirow{4}{*}{$\begin{array}{l}\text { Safe operation } \\
\text { and its status } \\
\qquad(40)\end{array}$} & Sudden departure, sudden braking, and sudden change of lane & 10 \\
\hline & Unnecessary use of klaxon, speeding, and wild driving & 10 \\
\hline & $\begin{array}{l}\text { Level of stopping at bus stop (failure to stop and avoiding } \\
\text { access to bus bay) }\end{array}$ & 10 \\
\hline & Attitude of driving (use of mobile phone) & 10 \\
\hline \multirow{3}{*}{$\begin{array}{l}\text { Kindness } \\
\text { (20) }\end{array}$} & $\begin{array}{l}\text { General kindness (route guidance, consideration for the } \\
\text { elderly, passenger movement and getting off, and uncouth } \\
\text { expression) }\end{array}$ & 10 \\
\hline & Drivers' attire (uniform and tidy image) & 5 \\
\hline & Greeting for passengers & 5 \\
\hline \multirow{3}{*}{$\begin{array}{l}\text { Guidance } \\
\text { system } \\
(20)\end{array}$} & Adequacy of guidance announcements at bus stops & 10 \\
\hline & $\begin{array}{l}\text { Adequacy of guidance signs } \\
\text { (normality of route and LED guidance panel) }\end{array}$ & 5 \\
\hline & $\begin{array}{l}\text { Status of driver's tablet and preparation of postcard to report } \\
\text { inconvenience }\end{array}$ & 5 \\
\hline \multirow{3}{*}{$\begin{array}{l}\text { Vehicle } \\
\text { management } \\
\text { (20) }\end{array}$} & $\begin{array}{l}\text { Condition of internal vehicle } \\
\text { (seat, window, lighting, bell for getting off, advertisement, } \\
\text { bus strap, and floor) }\end{array}$ & 10 \\
\hline & Vehicle's external cleanliness & 5 \\
\hline & Status of heating, cooling, and ventilating system & 5 \\
\hline Total & & 100 \\
\hline
\end{tabular}

Therefore, it is considered that Daejeon has continuously and systematically supported the monitoring groups since 2008 in order to boost public transport and improve the city's bus and traffic service. Daejeon has acted creatively, used a knowledge base that includes experts, and incorporated the results of the evaluations into its policy.

\section{Analysis of Service Satisfaction by Monitoring}

\subsection{Confirmation of Arriving on Time}

Among the evaluation items in 2012, the results for the question about the bus arriving on time showed that $48 \%$ of respondents answered "arrived exactly on time" and "arrived on time" and 36\% answered "general." The remaining 16\% answered "not arrived on time." With regard to the reason why the service interval between each bus was not regularly maintained, $46 \%$ of respondents selected "traffic congestion" as the main reason 
and the others chose "insufficient number of vehicles," "inconformity to vehicle allocation interval," and "illegal parking" in that order (see Figure 3).
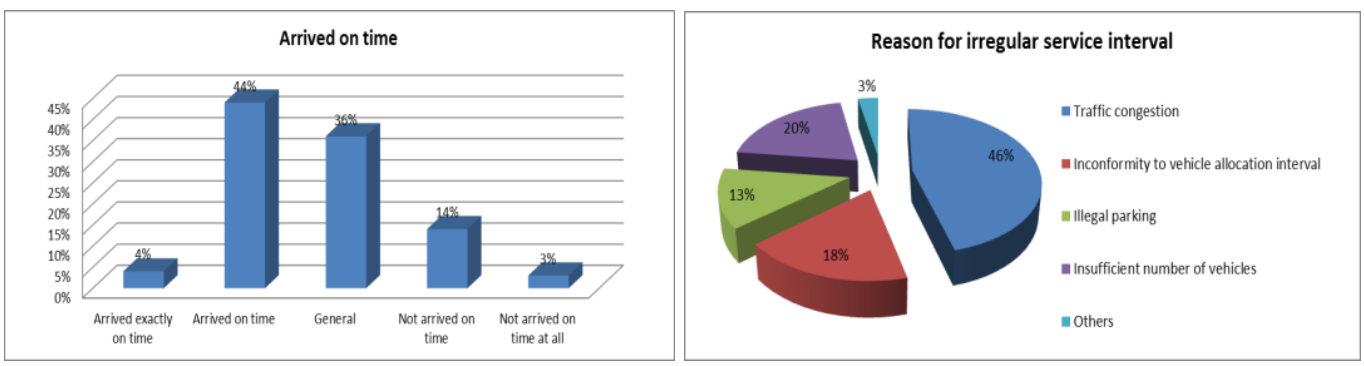

Figure 3. Arrival of the City Buses on Time and the Reason for Irregular Service Intervals

\subsection{Drivers' Status and City Bus Satisfaction Level}

With regard to the comments about consideration for passengers, greeting, and attitude, $38 \%$ of respondents answered "very kind" and " kind," which is a $2 \%$ increase compared with the prior year $(36 \%)$. With regard to conforming to the driving speed, departure and stopping protocol, traffic regulations, etc., 38\% answered "very satisfied" and " satisfied," which is an $8 \%$ increase compared with the prior year. With regard to issues that should be improved by drivers concerning their driving status, $28 \%$ selected "required to be improved because respondents are uncomfortable with a sudden start" and 14\% referred to incorrect halts at a bus bay, and violation of traffic signals and stop lines (see Figures 4 and 5).
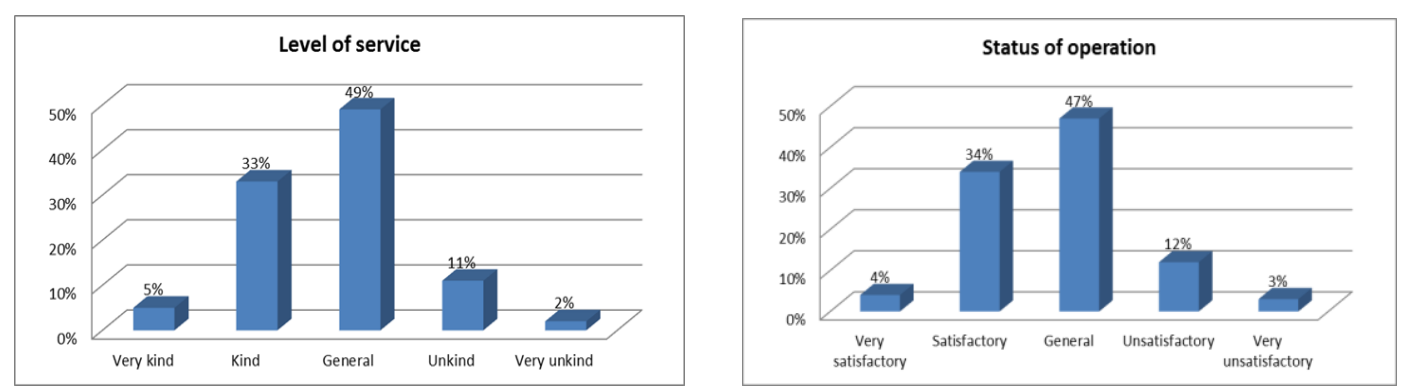

Figure 4. Satisfaction Evaluation Results of Level of Service and Status of Operation

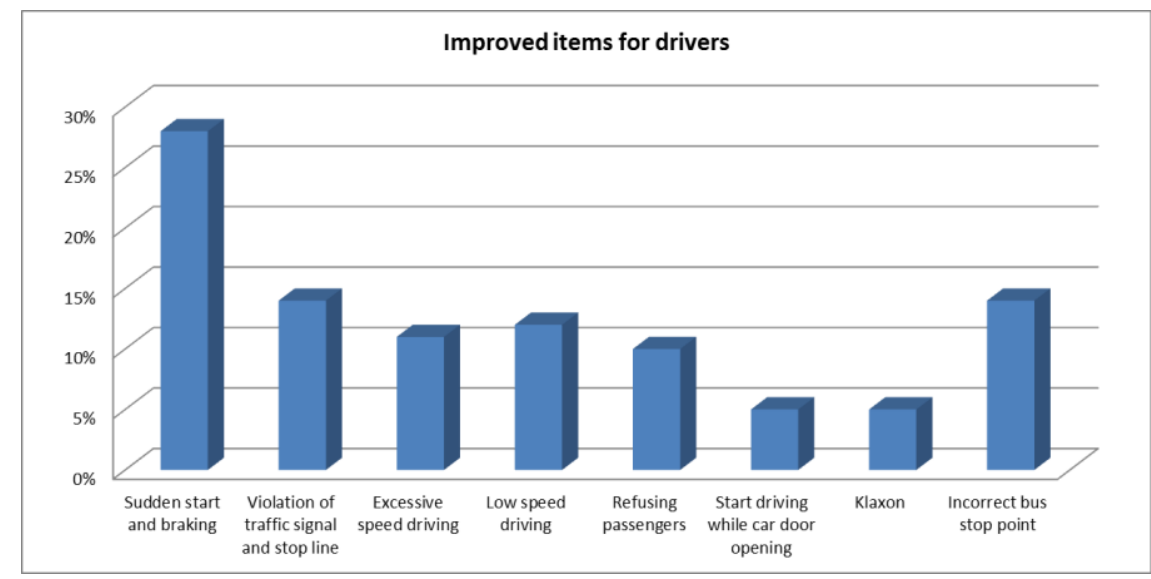

Figure 5. Improved Items for Drivers 


\subsection{Items to be improved}

With regard to the issues to be improved for city bus services, $18 \%$ of respondents answered "long waiting times," which was the highest level. 15\% answered "irregular operation intervals" and 13\% referred to "unkind drivers" and "wild and excessive speed driving" as issues to be improved (see Figure 6). Even though 18\% of respondents selected "long waiting times" as an item to be improved, this was significantly better than the 2010 figure of $37.70 \%$. In addition, "irregular operation intervals" improved from $35.6 \%$ in 2010 to $15 \%$ in 2012. All the items to be improved for city bus services in 2012 had clearly become better compared with the percentages in 2010 .

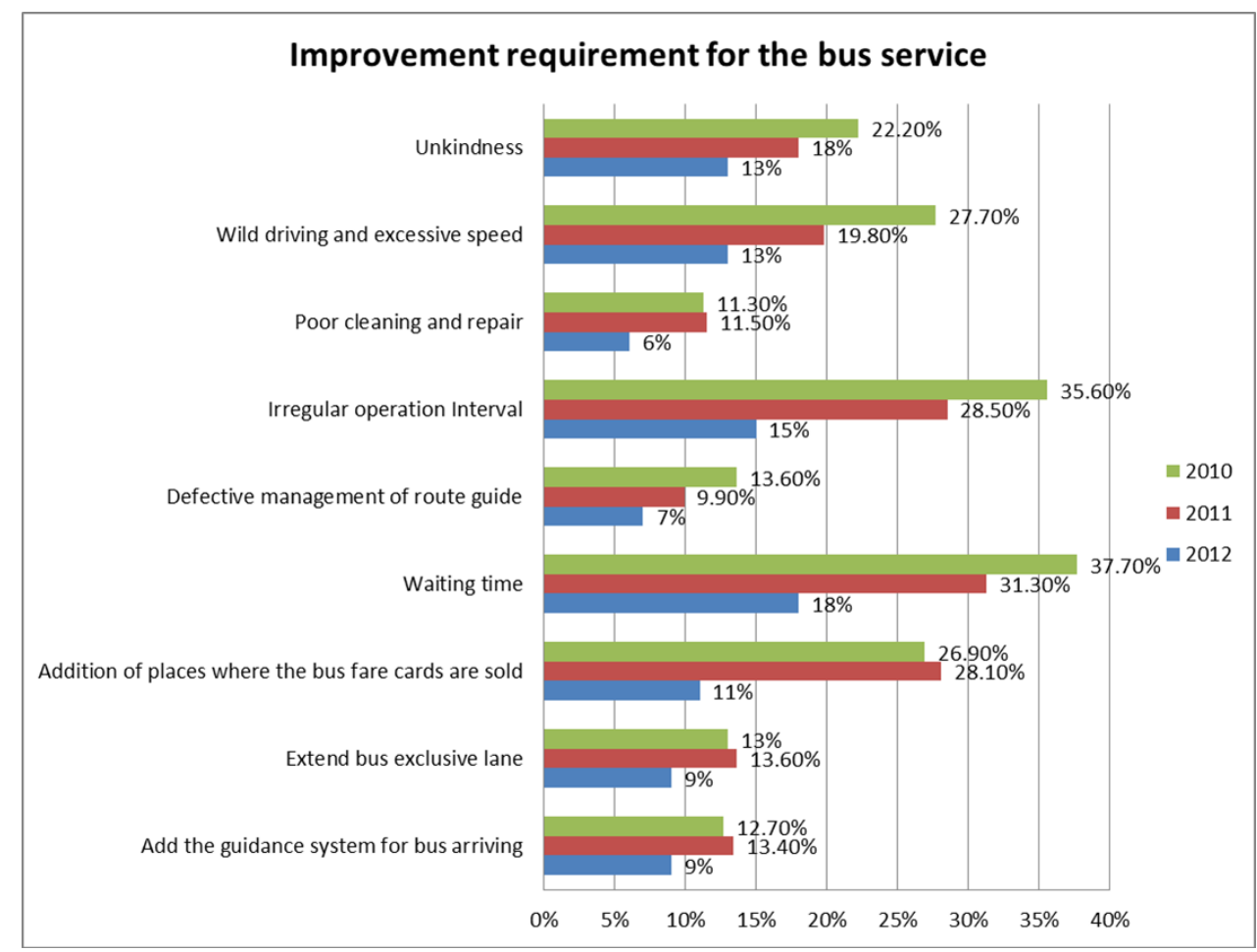

Figure 6. Improvement Requirement for the Bus Service

\subsection{Statistical Comparison of Improvement of the Bus Service for each Question}

The Bonferroni method was used to resolve multiple comparison problems and tested whether the improvement of the bus service from 2010 to 2012 for each question is statistically significant. The mean differences were compared for nine questions (see Figure 6). The null hypothesis is that the mean differences of the items to be improved are the same for each year, as follows.

$H_{0}: \mu_{2010}=\mu_{2011}=\mu_{2012}$

$H_{1}:$ not $H_{0}$

where

$\mu_{2010}$ : Mean differences of items to be improved in 2010

$\mu_{2011}$ : Mean differences of items to be improved in 2011

$\mu_{2012}$ : Mean differences of items to be improved in 2012 
The values for the Bonferroni test for the mean differences for each year were mostly more than the critical values at the $95 \%$ confidence level. This means that the bus service can be assumed to have continuously improved every year. Even though some items such as cleanliness, fare cards, bus lane, and arrival system were not statistically significant for annual comparison, these items in 2012 were clearly statistically significant compared with each question in 2010. Table 4 shows the statistical results of the comparisons for 2010, 2011, and 2012.

Table 4. Descriptive Statistics for Each Year

\begin{tabular}{|c|c|c|c|c|c|c|c|c|c|}
\hline & & \multirow{2}{*}{$\mathrm{N}$} & \multirow{2}{*}{ Mean } & \multirow{2}{*}{$\begin{array}{c}\text { Std. } \\
\text { Deviation }\end{array}$} & \multirow{2}{*}{$\begin{array}{l}\text { Std. } \\
\text { Error }\end{array}$} & \multicolumn{2}{|c|}{$\begin{array}{c}95 \% \text { confidence } \\
\text { interval }\end{array}$} & \multirow{2}{*}{$\begin{array}{l}\text { Min. } \\
\text { value }\end{array}$} & \multirow{2}{*}{$\begin{array}{l}\text { Max. } \\
\text { value }\end{array}$} \\
\hline & & & & & & $\begin{array}{l}\text { Lower } \\
\text { bound }\end{array}$ & $\begin{array}{l}\text { Upper } \\
\text { bound }\end{array}$ & & \\
\hline \multirow{4}{*}{ Unkindness } & 2010 & 140 & .2352 & .07476 & .00632 & .2227 & .2477 & .03 & .45 \\
\hline & 2011 & 140 & .1841 & .07732 & .00653 & .1712 & .1970 & -.03 & .39 \\
\hline & 2012 & 140 & .1372 & .07752 & .00655 & .1242 & .1501 & -.07 & .34 \\
\hline & Sum & 420 & .1855 & .08625 & .00421 & .1772 & .1938 & -.07 & .45 \\
\hline \multirow{4}{*}{$\begin{array}{l}\text { Excessive } \\
\text { Speed }\end{array}$} & 2010 & 140 & .2712 & .08158 & .00689 & .2576 & .2848 & .04 & .46 \\
\hline & 2011 & 140 & .1919 & .07671 & .00648 & .1791 & .2047 & .03 & .44 \\
\hline & 2012 & 140 & .1331 & .08123 & .00687 & .1196 & .1467 & -.16 & .31 \\
\hline & Sum & 420 & .1987 & .09776 & .00477 & .1894 & .2081 & -.16 & .46 \\
\hline \multirow{4}{*}{ Cleanliness } & 2010 & 140 & .1123 & .07692 & .00650 & .0994 & .1251 & -.12 & .31 \\
\hline & 2011 & 140 & .1138 & .08541 & .00722 & .0995 & .1281 & -.13 & .39 \\
\hline & 2012 & 140 & .0499 & .07967 & .00673 & .0366 & .0632 & -.17 & .27 \\
\hline & Sum & 420 & .0920 & .08589 & .00419 & .0838 & .1002 & -.17 & .39 \\
\hline \multirow{4}{*}{$\begin{array}{l}\text { Operational } \\
\text { Interval }\end{array}$} & 2010 & 140 & .3520 & .07665 & .00648 & .3392 & .3648 & .17 & .55 \\
\hline & 2011 & 140 & .2676 & .08385 & .00709 & .2536 & .2816 & -.01 & .44 \\
\hline & 2012 & 140 & .1385 & .08141 & .00688 & .1249 & .1521 & -.07 & .33 \\
\hline & Sum & 420 & .2527 & .11918 & .00582 & .2413 & .2641 & -.07 & .55 \\
\hline \multirow{4}{*}{$\begin{array}{c}\text { Route } \\
\text { Guidance }\end{array}$} & 2010 & 140 & .1455 & .07448 & .00629 & .1331 & .1580 & -.05 & .34 \\
\hline & 2011 & 140 & .0914 & .08025 & .00678 & .0780 & .1048 & -.15 & .30 \\
\hline & 2012 & 140 & .0641 & .07474 & .00632 & .0516 & .0766 & -.11 & .28 \\
\hline & Sum & 420 & .1003 & .08353 & .00408 & .0923 & .1084 & -.15 & .34 \\
\hline \multirow{4}{*}{$\begin{array}{l}\text { Waiting } \\
\text { Time }\end{array}$} & 2010 & 140 & .3774 & .05746 & .00486 & .3678 & .3870 & .19 & .52 \\
\hline & 2011 & 140 & .3191 & .05212 & .00440 & .3104 & .3278 & .15 & .44 \\
\hline & 2012 & 140 & .1736 & .04906 & .00415 & .1654 & .1818 & .03 & .28 \\
\hline & Sum & 420 & .2900 & .10077 & .00492 & .2804 & .2997 & .03 & .52 \\
\hline \multirow{3}{*}{$\begin{array}{l}\text { Fare } \\
\text { Cards }\end{array}$} & 2010 & 140 & .2699 & .08579 & .00725 & .2555 & .2842 & .05 & .49 \\
\hline & 2011 & 140 & .2709 & .07806 & .00660 & .2579 & .2840 & .11 & .50 \\
\hline & 2012 & 140 & .1070 & .08031 & .00679 & .0936 & .1204 & -.07 & .28 \\
\hline
\end{tabular}




\begin{tabular}{cccccccccc}
\hline & Sum & 420 & .2159 & .11203 & .00547 & .2052 & .2267 & -.07 & .50 \\
\hline \multirow{3}{*}{$\begin{array}{c}\text { Bus } \\
\text { Lane }\end{array}$} & 2010 & 140 & .1289 & .05517 & .00466 & .1197 & .1381 & .00 & .30 \\
& 2011 & 140 & .1364 & .04988 & .00422 & .1281 & .1447 & -.04 & .27 \\
& Sum & 420 & .1191 & .05432 & .00265 & .1139 & .1243 & -.06 & .30 \\
\hline \multirow{3}{*}{$\begin{array}{l}\text { Arrival } \\
\text { System }\end{array}$} & 2010 & 140 & .1206 & .08019 & .00678 & .1072 & .1340 & -.07 & .33 \\
& 2011 & 140 & .1282 & .08055 & .00681 & .1148 & .1417 & -.12 & .32 \\
& Sum & 420 & .1090 & .08199 & .00400 & .1012 & .1169 & -.12 & .33 \\
\hline
\end{tabular}

Table 5. Bonferroni Pairwise Comparisons

\begin{tabular}{|c|c|c|c|c|c|c|c|}
\hline & \multirow{2}{*}{ (I) Years } & \multirow{2}{*}{ (J) Years } & \multirow{2}{*}{$\begin{array}{c}\text { Mean } \\
\text { difference } \\
(\mathrm{I}-\mathrm{J})\end{array}$} & \multirow{2}{*}{ Std. Error } & \multirow{2}{*}{ Sig. } & \multicolumn{2}{|c|}{$\begin{array}{l}\text { 95\% Confidence } \\
\text { Interval }\end{array}$} \\
\hline & & & & & & $\begin{array}{l}\text { Lower } \\
\text { Bound }\end{array}$ & $\begin{array}{l}\text { Upper } \\
\text { Bound }\end{array}$ \\
\hline \multirow{6}{*}{$\begin{array}{l}\text { Unkindnes } \\
\qquad \mathrm{s}\end{array}$} & \multirow{2}{*}{2010} & 2011 & $.05115^{*}$ & .00915 & .000 & .0292 & .0731 \\
\hline & & 2012 & $.09808^{*}$ & .00915 & .000 & .0761 & .1201 \\
\hline & \multirow{2}{*}{2011} & 2010 & $-.05115^{*}$ & .00915 & .000 & -.0731 & -.0292 \\
\hline & & 2012 & $.04693 *$ & .00915 & .000 & .0249 & .0689 \\
\hline & \multirow{2}{*}{2012} & 2010 & $-.09808 *$ & .00915 & .000 & -.1201 & -.0761 \\
\hline & & 2011 & $-.04693 *$ & .00915 & .000 & -.0689 & -.0249 \\
\hline \multirow{6}{*}{$\begin{array}{c}\text { Excessive } \\
\text { Speed }\end{array}$} & \multirow{2}{*}{2010} & 2011 & $.07929 *$ & .00955 & .000 & .0563 & .1022 \\
\hline & & 2012 & $.13808 *$ & .00955 & .000 & .1151 & .1610 \\
\hline & \multirow{2}{*}{2011} & 2010 & $-.07929 *$ & .00955 & .000 & -.1022 & -.0563 \\
\hline & & 2012 & $.05879 *$ & .00955 & .000 & .0358 & .0817 \\
\hline & \multirow{2}{*}{2012} & 2010 & $-.13808 *$ & .00955 & .000 & -.1610 & -.1151 \\
\hline & & 2011 & $-.05879 *$ & .00955 & .000 & -.0817 & -.0358 \\
\hline \multirow{6}{*}{ Cleanliness } & \multirow{2}{*}{2010} & 2011 & -.00154 & .00965 & 1.000 & -.0247 & .0217 \\
\hline & & 2012 & $.06236^{*}$ & .00965 & .000 & .0392 & .0856 \\
\hline & \multirow{2}{*}{2011} & 2010 & .00154 & .00965 & 1.000 & -.0217 & .0247 \\
\hline & & 2012 & $.06390 *$ & .00965 & .000 & .0407 & .0871 \\
\hline & \multirow{2}{*}{2012} & 2010 & $-.06236^{*}$ & .00965 & .000 & -.0856 & -.0392 \\
\hline & & 2011 & $-.06390 *$ & .00965 & .000 & -.0871 & -.0407 \\
\hline \multirow{6}{*}{$\begin{array}{l}\text { Operational } \\
\text { Interval }\end{array}$} & \multirow{2}{*}{2010} & 2011 & $.08442 *$ & .00964 & .000 & .0612 & .1076 \\
\hline & & 2012 & $.21348^{*}$ & .00964 & .000 & .1903 & .2367 \\
\hline & \multirow{2}{*}{2011} & 2010 & $-.08442 *$ & .00964 & .000 & -.1076 & -.0612 \\
\hline & & 2012 & $.12906^{*}$ & .00964 & .000 & .1059 & .1522 \\
\hline & \multirow{2}{*}{2012} & 2010 & $-.21348 *$ & .00964 & .000 & -.2367 & -.1903 \\
\hline & & 2011 & $-.12906 *$ & .00964 & .000 & -.1522 & -.1059 \\
\hline \multirow{6}{*}{$\begin{array}{c}\text { Route } \\
\text { Guidance }\end{array}$} & \multirow{2}{*}{2010} & 2011 & $.05413 *$ & .00915 & .000 & .0321 & .0761 \\
\hline & & 2012 & $.08140 *$ & .00915 & .000 & .0594 & .1034 \\
\hline & \multirow{2}{*}{2011} & 2010 & $-.05413 *$ & .00915 & .000 & -.0761 & -.0321 \\
\hline & & 2012 & $.02727 *$ & .00915 & .009 & .0053 & .0493 \\
\hline & \multirow{2}{*}{2012} & 2010 & $-.08140^{*}$ & .00915 & .000 & -.1034 & -.0594 \\
\hline & & 2011 & $-.02727 *$ & .00915 & .009 & -.0493 & -.0053 \\
\hline \multirow{2}{*}{$\begin{array}{l}\text { Waiting } \\
\text { Time }\end{array}$} & \multirow{2}{*}{2010} & 2011 & $.05826 *$ & .00633 & .000 & .0430 & .0735 \\
\hline & & 2012 & $.20376^{*}$ & .00633 & .000 & .1885 & .2190 \\
\hline
\end{tabular}




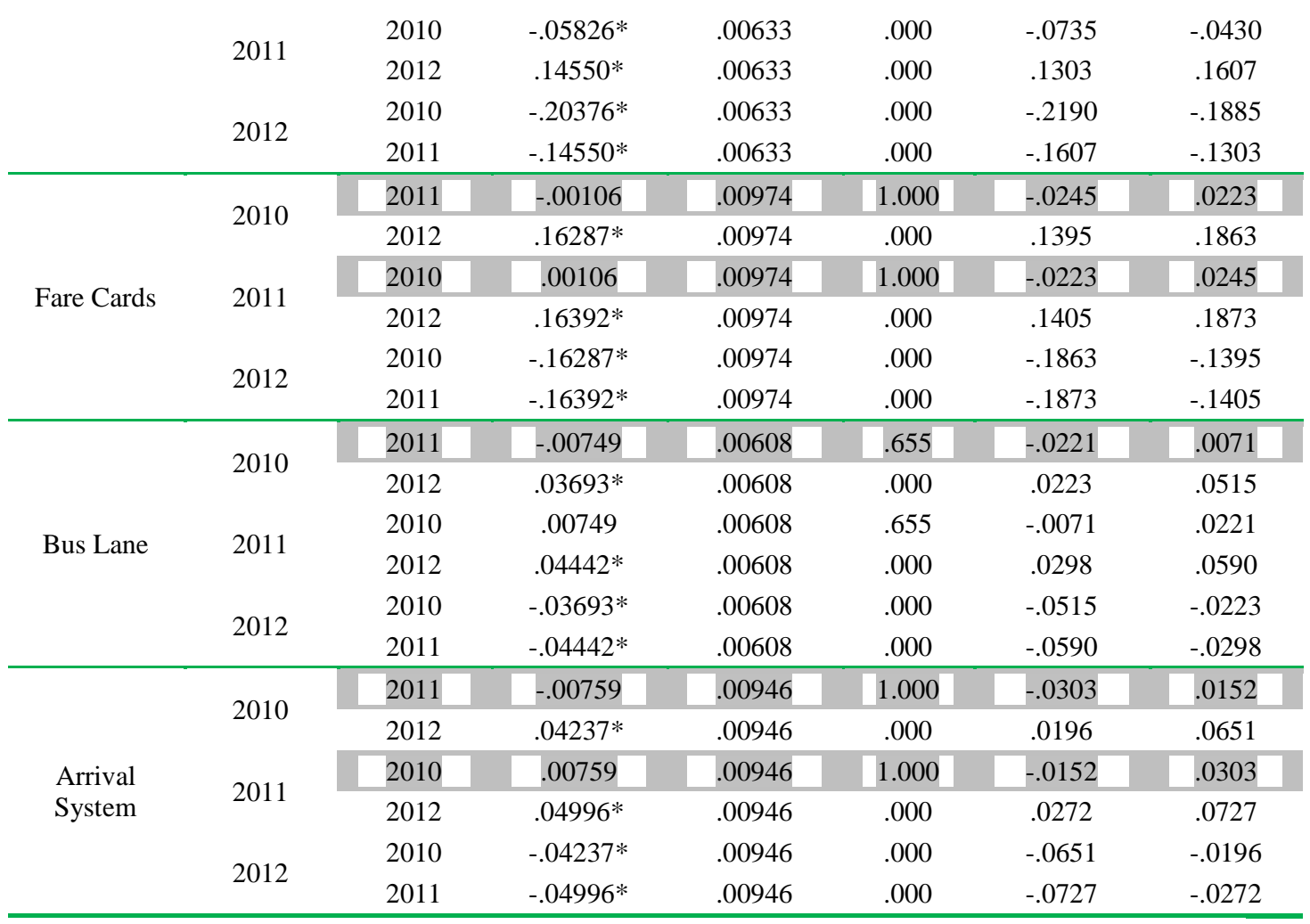

\section{Conclusion and Future Study}

This study introduced the elements of an innovative strategy to improve the city bus service in Daejeon using the 4Ps concept and boost public transport. The strategy is based on the civil participation model and has organized civil monitoring groups for the city bus service since 2008, thereby improving the service and encouraging the use of public transport. The strategy's outcome and efforts have been taken into consideration in this paper.

With regard to the general satisfaction level of citizens for the city bus service in Daejeon Metropolitan City in 2012, 67\% of respondents answered "very satisfied" and "satisfied," 27\% answered "so-so," and 5\% said "unsatisfied" and "very unsatisfied." It is considered that most Daejeon citizens have a positive attitude toward the general service provided by the city buses in Daejeon. With regard to the improvement of the city bus service since 2008 when civil monitoring groups began monitoring, positive answers have increased as follows: $39.4 \%$ in 2008, 50.3\% in 2009, 55\% in 2010, and 59.8\% in 2011. These percentages show rapidly increasing value.

The efforts to cooperate made by Daejeon city, bus companies, and citizens have brought positive general recognition of the city bus service. In addition, the complaints registered on the internet through the civil monitoring group have been incorporated into policy or otherwise acted upon to ensure an improvement structure with a virtuous cycle. Further, other municipalities benchmark the experience and efforts in Daejeon for their own civil monitoring groups and city bus services. Thus, it is necessary to construct traffic services creatively based on knowledge and experience, and also enable organizations to develop methods of public transport support. 


\section{References}

[1] Alcotra, "Best Practices Database for Living Labs", (2011).

[2] S. A. Ahmed and S. M. Ali, "People as Partner: Facilitating People's Participation in Public-Private Partnerships for Solid Waste Management", Habitat International, vol. 30, (2006), pp. 781-796.

[3] S. Chakrabarti, A. Majumder and S. Chakrabarti, "Public-Community Participation in Household Waste Management in India: an Operational Approach”, Habitat International, vol. 33, (2009), pp. 125-130.

[4] M. Eriksson, V. Niitamo and S. Kulkki, "State-of-the-Art in Utilizing Living Labs Approach to UserCentric ICT Innovation - a European Approach", CDT at Luleå University of Technology, Sweden, Nokia Oy, Centre for Knowledge and Innovation Research at Helsinki Scholl of Economics, Finland, (2005).

[5] C. S. King, K. M. Feltey and B. O. Susel, "The Question of Participation: Toward Authentic Public Participation in Public Administration", Public Administration Review, vol. 58, no. 4, (1998), pp. 317326.

[6] G. Seyfang, S. Hielscher, T. Hargreaves, M. Martiskainen and A. Smith, "A Grassroots Sustainable Energy Niche? Reflections on Community Energy Case Studies", 3S Working Paper, (2013), pp. 20132021.

[7] W. Song, J. Song, E. Lee and M. Park, "Civil Participatory Innovation Strategies for Sustainable City", STEPI Issue \& Policy 2013-12, (2013).

[8] D. L. Tulloch and T. Shapiro, "The Interaction of Data Access and Public Participation: Impacting GIS Users' Success?”, URISA Journal, vol. 15, (2003), pp. 55-60.

[9] T. Yigitcanlar and S. Lee, "Korean Ubiquitous-eco-city: A Smart-Sustainable Urban Form or a Branding Hoax?", Technological Forecasting and Social Change, vol. 89, (2014), pp. 100-114.

[10] http://bus.green21.or.kr/.

[11] www.dgag21.or.kr.

[12] www.gwangju.go.kr. 